\title{
Essential elements in the different types of fruits, soil, and water samples collected from Markazi province, Iran: a health risk assessment study
}

\begin{abstract}
Mohammad Rezaei ${ }^{1,2}$, Ali Akbar Malekirad ${ }^{3}$, Maryam Jabbari ${ }^{4}$, Maryam Karimi-Dehkordi ${ }^{5}$, Bahareh Ghasemidehkordi ${ }^{6}$, Hossein Teimoory ${ }^{7}$, Yadolah Fakhri ${ }^{8}$, Amin Mousavi Khaneghah,"

${ }^{1}$ Department of Food Hygiene, Faculty of Veterinary Medicine, University of Tehran, Tehran, Iran; ${ }^{2}$ Department of Food Safety and Hygiene, School of Public Health, Tehran University of Medical Sciences, Tehran, Iran; ${ }^{3}$ Department of Biology, Payame Noor University, Tehran, Iran; ${ }^{4}$ Department of Public Health, School of Paramedical and Health, Zanjan University of Medical Sciences, Zanjan, Iran; ${ }^{5}$ Department of Clinical Sciences, Faculty of Veterinary Medicine, Shahrekord Branch, Islamic Azad University, Shahrekord, Iran; ${ }^{6}$ Department of Biochemistry, Payame Noor University, Isfahan, Iran; ${ }^{7}$ Department of Natural Resources Engineering - Environment - Habitats and Biodiversity, Tehran Sciences and Research Branch, Islamic Azad University, Tehran, Iran; ${ }^{8}$ Student Research Committee, Department of Environmental Health Engineering, Shahid Beheshti University of Medical Sciences, Tehran, Iran; ${ }^{9}$ Department of Food Science, Faculty of Food Engineering, University of Campinas (UNICAMP), São Paulo. Brazil
\end{abstract}

"Corresponding Author: Amin Mousavi Khaneghah, Department of Food Science, Faculty of Food Engineering, University of Campinas (UNICAMP), Rua Monteiro Lobato, 80. Caixa Postal: 6121. CEP: 13083-862, Campinas, São Paulo, Brazil. Email: mousavi@unicamp.br

Received: 23 June 2020 / Accepted: 15 August 2020 / Published: 28 August 2020

(c) 2020 Codon Publications

OPEN ACCESS C);(1) (1)

ORIGINAL ARTICLE

\begin{abstract}
Fruits could contain elements in various concentrations, which can have both positive and negative impacts on human health. The concentrations of essential elements, including Iron (Fe), Copper $(\mathrm{Cu})$, Zinc $(\mathrm{Zn})$, Manganese $(\mathrm{Mn})$, and Chromium $(\mathrm{Cr})$ in five types of fruits, namely, peach, apple, grape, nectarine, and golden plum, and the soil and irrigation water from six industrial zones of Markazi province, Iran, were evaluated using an inductively coupled plasma-optical emission spectroscopy (ICP-OES) technique. The noncarcinogenic risk was assessed by determining the target hazard quotient and the Monte Carlo simulation model. The highest concentrations of Fe, $\mathrm{Mn}$, and $\mathrm{Cr}$ were observed in golden plum, while the highest concentrations of $\mathrm{Cu}$ and $\mathrm{Zn}$ were noted in grape and apple, respectively. The order of the mean of concentrations of elements in the soil and water samples were Fe $>\mathrm{Mn}>\mathrm{Zn}>\mathrm{Cu}>\mathrm{Cr}$. The transfer factor (TF) results indicate that studied fruits could not absorb a high amount of these elements from the soil ( $\mathrm{TF}<1)$. Target hazard quotient values of these elements in both adults and children were ranked as $\mathrm{Cr}>\mathrm{Cur}>\mathrm{Fe}>\mathrm{Mn}>\mathrm{Zn}$. The target hazard quotient was 95\% and total target hazard quotient was $<1$, meaning that the consumption of fruits is safe for consumers.
\end{abstract}

Keywords: essential elements; food safety; fruits; health risk assessments; nutritional assessment

\section{Introduction}

Fruits have been recognized as one of the most important components of diet owing to their valuable content of different nutrients, such as minerals, vitamins (mainly $\mathrm{C}$ and $\mathrm{A}$ ), antioxidants, water, polysaccharides, sugars, and fibers (Grembecka and Szefer, 2013). In this regard, it has been suggested that at least $400 \mathrm{~g}$ of fruits and veggies should be consumed as part of daily diet to maintain good health and prevent diseases (WHO, 2018). The intake of fruits and vegetables is inversely associated with the incidence of chronic disease, hypertension, diabetes, 
cataracts, cancers, and cardiovascular diseases (Prakash et al., 2012). Fruits could contain essential and nonessential elements in varying concentrations, which in turn can impact human health (Wang et al., 2015).

Microelements like Iron (Fe), Copper $(\mathrm{Cu})$, Zinc $(\mathrm{Zn})$, Manganese $(\mathrm{Mn})$, and Chromium $(\mathrm{Cr})$ are essential for several biochemical and physiological pathways (Bagdatlioglu et al., 2010). In addition, these elements are crucial for lipids and carbohydrates metabolism, as well as the synthesis of proteins (Grembecka and Szefer, 2013). Some elements found in fruits offer strong antioxidant activity, and they can act as a cofactor of antioxidant enzymes such as superoxide dismutase ( $\mathrm{Cu}, \mathrm{Zn}-\mathrm{SOD}, \mathrm{Mn}-\mathrm{SOD})$, glutathione peroxidase (Se), and catalase (contains four porphyrin heme [Fe] groups) (Sajib et al., 2014).

Fe, as a very abundant essential element on the Earth, plays a vital role in the body (Abbaspour et al., 2014). It binds to the proteins like hemoproteins, heme enzymes, and nonheme compounds such as transferrin and ferritin (carrier proteins of Fe). The significant part of Fe in the soil is insoluble and not available for plants. The consumption of cereals, fruits, legumes, and vegetables can provide the required amounts of nonheme $\mathrm{Fe}$ (Trumbo et al., 2001). In this regard, the shortage of Fe in the diet is a significant contributor to anemia, which is a well-known health issue in many countries (Abbaspour et al., 2014), including Iran (Akbari et al., 2017).

On the contrary, the intake of Fe in a high dose could have some adverse effects on the gastrointestinal system, which can result in cardiovascular disease (Korkmaz et al., 2019b; Trumbo et al., 2001), Parkinson's disease, Alzheimer's disease, and type-2 diabetes (Korkmaz et al., $2019 b) . \mathrm{Cu}$ is a cofactor for various enzymes and also has several functions in the immune system, antioxidant defense, and neuropeptide synthesis (Prohaska and Lukasewycz, 1990). Cu deficiency can cause impaired development in the cardiovascular system, bone malformation, ongoing neurologic and immunologic abnormalities, and also an alteration in cholesterol metabolism in adults (Bost et al., 2016). On the contrary, excessive intake of $\mathrm{Cu}$ has adverse effects on the gastrointestinal tract and liver (Scheinberg and Sternlieb, 1996) and also causes kidney disorders (Korkmaz et al., 2019a) such as Wilson's disease (Trumbo et al., 2001). $\mathrm{Zn}$ is one of the essential microelements in all stages of life, especially during pregnancy and infancy (McArdle and Ashworth, 1999). It promotes healthy growth and stimulates the activity of more than 100 enzymes, carbohydrate metabolism and growth, and the development of the fetus. Zn deficiency causes a decrease in nerve conduction, mental lethargy, neurosensory disease, skin lesions, acrodermatitis, infertility, and hypogonadism (Brown et al., 2001). Mn is crucial in the formation of bones, connective tissues, amino acids, carbohydrates, and lipid metabolism. However, exposure to high levels of Mn causes some adverse effects on the nervous system (Araújo et al., 2019; Horning et al., 2015). $\mathrm{Cr}$ aids in glucose, proteins, and lipids metabolism. However, it is highly detrimental to humans, and high concentrations of $\mathrm{Cr}$ can result in anemia, hemolysis, liver, and renal failure (Clarkson, 1991). On the other hand, deficiency of $\mathrm{Cr}^{+3}$ causes disturbance in blood glucose, especially in diabetic patients (Sun et al., 2015).

For many years, uptake of some elements, such as Fe and $\mathrm{Zn}$, were not considered as a threat to human health. In contrast, deficiency of these essential elements was the primary concern in developing countries (Akbari et al., 2017). Anemia (WHO, 2001) and death under the age of 5 years due to infection as a result of Fe and $\mathrm{Zn}$ deficiency are still major global health problems that are related to low bioavailability of these essential elements and less intake in diet (Bailey et al., 2015). Like other underdeveloped countries, in Iran, Fe intake is below the recommended levels (Aberournand, 2012). However, studies about metal contamination in different parts of Iran showed that the bioavailability of these essential elements is increasing due to an increase in food contamination (Dadar et al., 2017; Shahsavani et al., 2017; Zafarzadeh et al., 2018). Moreover, unlike Western diet wherein meat is a predominant component, Iranian diet relies heavily on agricultural products like rice, fruits, and vegetables (Hashemi et al., 2017). In spite of these elements being essential for humans, their toxicity and bioavailability in food in a specific concentration are of immense concern to public health. In this context, some assessments and monitoring of heavy metals in agricultural products have been conducted in different parts of Iran (Derakhshan et al., 2016). However, there is no information about the accumulation of essential elements in fruits farmed close to industrial-agricultural sites, such as Markazi province. The previously conducted study reported that soil and irrigation water of Markazi province were excessively polluted with lead $(\mathrm{Pb})$ and mercury $(\mathrm{Hg})$ due to the industrial chemicals and effluents (Ghasemidehkordi et al., 2018b); however, there is no record regarding the levels of essential elements in the fruits, soil, and water of this area. Therefore, an investigation is vital for the production of best-quality fruits for inhabitants. In the previous studies, only one study investigated the level of elements, such as $\mathrm{Fe}, \mathrm{Cu}, \mathrm{Zn}, \mathrm{Mn}, \mathrm{Cr}$, calcium $(\mathrm{Ca}$ (, potassium $(\mathrm{K})$, magnesium $(\mathrm{Mg})$, phosphorus $(\mathrm{P})$ and selenium (Se), in hen egg-white in the Markazi province (Rezaei et al., 2016). However, no studies have been conducted to determine the level of essential elements in fruits produced in this area.

In this context, this is the first attempt to employ an ICPOES technique to investigate the concentrations of Fe, $\mathrm{Cu}, \mathrm{Zn}, \mathrm{Mn}$, and $\mathrm{Cr}$ in five of the most popular fruits. The level of these elements in irrigation water and the 
surrounding soil was measured to calculate the transfer factor (TF) value. Moreover, target hazard quotient (THQ), total target hazard (TTHQ), hazard index (HI), and estimated daily intake (EDI) for different groups of consumers in the study area was assessed.

\section{Material and Methods}

\section{Study area}

Six different sites of the Markazi province, namely, Saveh, Khondab, Khomein, Mahallat, Tafresh, and Delijan were selected considering their proximity to several big industrial complexes in the province, including an oil refinery, a petrochemical company, and an aluminum company for the sampling of fruits, water, and soil (Figure 1). Markazi province is located in the western part of Iran (at a latitude and longitude of $34^{\circ} 05^{\prime} 30.26^{\prime \prime} \mathrm{N}$ and $49^{\circ} 41^{\prime}$ $20.98^{\prime \prime} \mathrm{E}$, respectively), with an average height of 1,750 $\mathrm{m}$ above sea level and a mean annual precipitation of $278 \mathrm{~mm} /$ year (relative humidity of 46\%). The mean temperature is $12.8^{\circ} \mathrm{C}$, and minimum and maximum annual absolute temperatures were -13 to $-35^{\circ} \mathrm{C}$ and 36 to $49^{\circ} \mathrm{C}$, respectively. The population of this area is about 1.43 million.

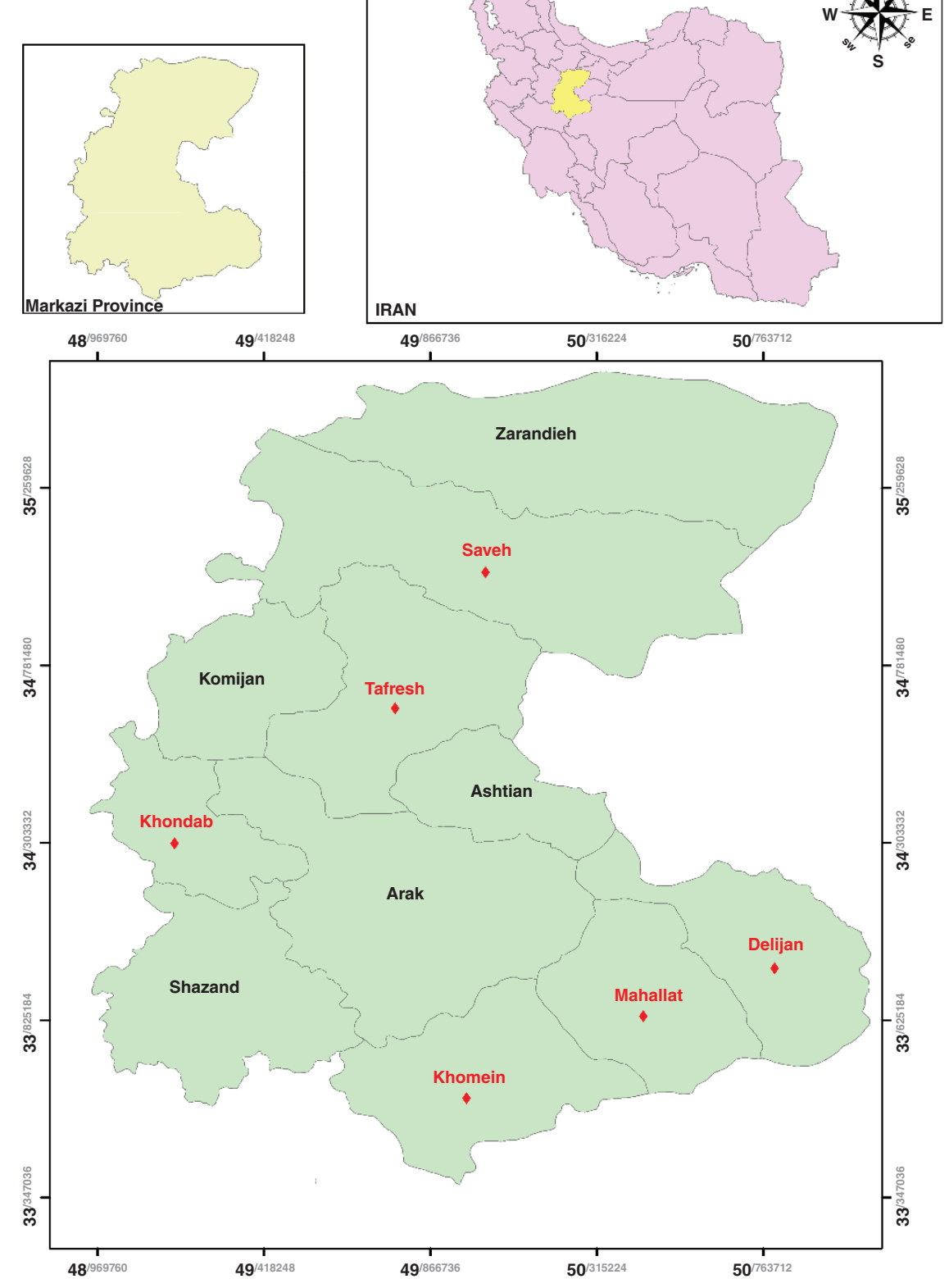

Figure 1. Map of the sampling localities at Markazi province. 


\section{Chemical and reagent}

All chemicals such as $\mathrm{HNO}_{3}, \mathrm{H}_{2} \mathrm{SO}_{4}$, and $\mathrm{HClO}_{4}$ as well as the standards and stock solutions of analytical grade [Fe (Chemical Abstracts Service; CAS) Number 743989-6), Mn (CAS Number 7439-96-5), Zn (CAS Number 7440-66-6), $\mathrm{Cu}$ (CAS Number 7440-50-8), and Cr (CAS Number 7440-47-3)] were obtained from Merck (Darmstadt, Germany) and were prepared by diluting in ultrapure water.

\section{Sample collection (fruits, water, and soil)}

Five popular fruits species commonly known as peach (Prunus persica), apple (Malus pumila), grape (Vitis vinifera $L$.), nectarine (P. persica var. nucipersica), and golden plum or Mirabelle plum (P. domestica subsp. syriaca) (triplicate) were collected from selected sites of Markazi. Three samples of each fruit species $(1 \mathrm{~kg}$ of each sample) were collected. Therefore, 15 samples obtained from the six selected regions resulted in a total of 90 samples (five types of fruits in triplicate from six sampling areas). Also, from each sampling site, $1 \mathrm{~kg}$ of soil from around the same trees from which the fruits were plucked was taken (by excavating $1.5 \mathrm{~m}$ radial distance from the plant center) and placed into polyethylene bags and preserved in a frozen condition in the laboratory in order to reduce the risk of hydrolysis and oxidation. Samples were taken from 10 to $15 \mathrm{~cm}$ depth in the ground while the grass, stones, weeds, and trash were discarded. Water samples (1 $\mathrm{L}$ of each sample) was collected in clean glass bottles from irrigation sources in experimental zones.

\section{Preparation of samples (fruits, water, and soil)}

The fruits were collected from the field in polyethylene bags and were transferred to the laboratory as soon as possible to reduce unwanted pollution. Fruit samples were digested by the modified method of Li et al. (2019) as follows:

Samples were washed carefully with tap water, and then with ultrapure water; they were chopped to small pieces (only edible parts of the fruit were used). All samples were oven-dried at $70^{\circ} \mathrm{C}$ for $48 \mathrm{~h}$. Then, they were crushed to the small fragments and stored in dark polyethylene bottles for the next step. Fruit samples (1 g of dried fruits) were acid digested with the aid of a high-pressure microwave-assisted apparatus (MARS 5, CEM Corporation; a maximum power of $1400 \mathrm{~W}$, a power of $100 \%, 20 \mathrm{mi}$ ramp adjusted, a pressure of $180 \mathrm{psi}, 210^{\circ} \mathrm{C}$, and a hold time of $10 \mathrm{~min}$ ) after incorporation of $15 \mathrm{~mL}$ of the three acid mixtures to the test tubes, namely, $\mathrm{HNO}_{3}(70 \%), \mathrm{H}_{2} \mathrm{SO}_{4}$ (65\%), and $\mathrm{HClO}_{4}(70 \%)$, in 5:1:1 ratio. Ultrapure water was added to the remaining solution until it reached $25 \mathrm{~mL}$. Finally, it was subjected to further analysis by an ICP-OES instrument (Shakya and Khwaounjoo, 2013). All calculations were based on fresh weight and the edible portion of fruits.

Soil samples were dried in an oven $\left(70^{\circ} \mathrm{C}\right.$ for $\left.24 \mathrm{~h}\right)$ before treatment. Soil and water was prepared based on the previously conducted methods (Ghasemidehkordi et al., 2018b; Shakya and Khwaounjoo, 2013).

\section{ICP-OES analysis}

The fruit, soil, and water samples were analyzed for $\mathrm{Fe}, \mathrm{Cu}$, $\mathrm{Zn}, \mathrm{Mn}$, and $\mathrm{Cr}$ by ICP-OES (EOP, Spectroacros, Germany. Model Varian Vista-MPX). The ICP-OES instrument was used according to previously recommended conditions (Ghasemidehkordi et al., 2018a; Shakya and Khwaounjoo, 2013). Equipped with an ultrasonic nebulizer and an autosampler, argon (carrier gas with purity $99.999 \%$ ), the flow rate for modified lichte nebulizer was $0.7 \mathrm{~L} / \mathrm{min}$ and for the coolant was $13 \mathrm{~L} / \mathrm{min}$. The speed of the fourchannel peristaltic pump in pre-flush condition: $60 \mathrm{rpm}$ for $45 \mathrm{~S}$ and analysis: $30 \mathrm{rpm}$, power level: $1400 \mathrm{KW}$.

\section{Quality assurance}

Individual stock standard solutions $(10 \mu \mathrm{g} / \mathrm{mL})$ were plotted based on the previously conducted studies) 0.1, $0.5,2.5,10,100,200,300$, and $500 \mu \mathrm{L}$ of mixed standard stock solution to $10 \mathrm{~g}$ of blank samples (Ghasemidehkordi et al., 2018a, 2018b; Rezaei et al., 2017). The linearity of the method was assessed using the calibration curve, and it was plotted for each element in the standard solution and food matrix according to the correlation coefficient $\left(R^{2}\right)$ through linear regression analysis.

The sensitivity of the used methods was evaluated using the limit of detection (LOD) (signal-to-noise $-\mathrm{S} / \mathrm{N}$ ratios of $1 / 3$ ) and limit of quantification (LOQ) (S/N 1/10).

Spiked fruits, soil, and blank water samples at concentrations of $15,25,75,150,250,500$, and $750 \mu \mathrm{g} / \mathrm{mL}$ were in triplicates, and the recoveries were measured according to previous investigations (Ghasemidehkordi et al., 2018b).

\section{Transfer factor}

Transmission of elements from soil to plant tissues is defined as TF. It is calculated as a ratio of concentration of elements in plant tissues to the concentration of the same elements in the surrounding soil (Lato et al., 2012). TF $>1$ indicates the plant's high absorption of elements from the soil. 


\section{Probabilistic health risk assessment}

\section{Estimated daily intake}

The calculation of estimated daily intake (EDI) ( $\mu \mathrm{g} / \mathrm{kg}-\mathrm{d})$ was done according to the following equation (Adel et al., 2016).

$$
\mathrm{EDI}=\frac{\mathrm{C} \times \mathrm{IR} \times \mathrm{EF} \times \mathrm{ED} \times \mathrm{CF}}{\mathrm{BW} \times \mathrm{ATn}} \text { Equation (1) }
$$

$\mathrm{C}$ is a concentration of individual essential elements; IR, ingestion rate; $E F$, exposure frequency; ED, exposure duration; BW, body weight; ATn, average lifespan time, and CF, convert factor. Values of all parameters in equation (1) are presented in Table 1.

\section{Noncarcinogenic risk assessment}

Noncarcinogenic risk of the elements in fruit samples was measured via THQ based on the following equation (Shahsavani et al., 2017; Zafarzadeh et al., 2018).

$$
T H Q_{i}=\frac{E D I}{R f D}
$$

Equation (2)

where EDI $(\mu \mathrm{g} / \mathrm{kg}-\mathrm{d})$ is estimated daily intake and RfD is the reference dose of the essential elements due to the oral pathway. Oral RfD for $\mathrm{Fe}, \mathrm{Cu}, \mathrm{Zn}, \mathrm{Mn}, \mathrm{Cr}^{+6}$ is $700,40,300$, 140 , and $3 \mu \mathrm{g} / \mathrm{kg}$-d, respectively (EPA, 2017).

Likewise, the TTHQ was calculated through the following equation (Shi et al., 2011; USEPA, 2015).

$$
\mathrm{TTHQ}=\sum_{\mathrm{i}=1}^{\mathrm{n}} \mathrm{THQ} \quad \text { Equation (3) }
$$

where TTHQ is the sum of THQ of each essential element in fruits when THQ and/or TTHQ > 1, the health risk is considerable; if THQ and/or TTHQ $\leq 1$, there is no likelihood of a health risk (Dadar et al., 2017).
The quota of essential elements in TTHQ was determined through the current equation (Shi et al., 2011; USEPA, 2015):

$$
\mathrm{Q}=\frac{\mathrm{THQ}}{\mathrm{TTHQ}} \times 100
$$

Equation (4)

where $\mathrm{Q}$ is a quota of essential elements (\%), THQ is THQ of any element, and TTHQ is the total THQ.

\section{Monte Carlo simulation model}

Uncertainties can be undertaken in risk assessment (Chen et al., 2012). High uncertainty can expected while a single-point value like a concentration in the health risk assessment was used. Therefore, Monte Carlo simulation (MCS) can be used as a model to decrease the uncertainties (Ru et al., 2013). Probabilistic risk assessment was done using Crystal Ball software (version 11.1.2.4, Oracle, Inc., USA). Ninety five percent of THQ was a benchmark for endangered population. The number of 10,000 was also selected as repetitions in the model $(\mathrm{Qu}$ et al., 2012).

\section{Statistical analysis}

The mean value, standard deviation (SD), and one-way analysis of variance (ANOVA) test were conducted to determine the concentrations of essential elements in samples. $\mathrm{P}<0.05$ was considered statistically significant. These analyses were performed using the SPSS v.22 (Chicago, IL, USA).

\section{Results and Discussion}

\section{Quality assurance}

All essential elements presented good linearity. The cor-

\begin{tabular}{|c|c|c|c|c|}
\hline Parameter & Definition & Unit & Value & References \\
\hline EDI & Estimated daily intake & $\mathrm{mg} / \mathrm{kg}-\mathrm{d}$ & & \\
\hline C & Concentration & $\mu g / k g$ & & \\
\hline IR & Ingestion rate & $\mathrm{g} / \mathrm{d}$ & $\begin{array}{l}\text { Children }=12 \\
\text { Adults }=30\end{array}$ & (Fathabad et al., 2018) \\
\hline EF & Exposure frequency & $\mathrm{d} /$ Year & 350 & \\
\hline ED & Exposure duration & Years & $\begin{array}{l}\text { Children }=6 \\
\text { Adults }=30\end{array}$ & (USEPA, 2015) \\
\hline BW & Body weight & $\mathrm{Kg}$ & $\begin{array}{l}\text { Children }=15 \\
\text { Adults }=70\end{array}$ & \\
\hline Atn & Average lifespan time for noncarcinogenic risk & days & $\begin{array}{l}\text { Children }=2190 \\
\text { Adults }=10,950\end{array}$ & (USEPA, 2015) \\
\hline CF & Convert factor $\mu \mathrm{g}$ to $\mathrm{mg}$ & & $10^{-3}$ & \\
\hline
\end{tabular}
relation factors for the essential elements were between 0.9974 and 0.9998 .

Table 1. Included parameters to health risk assessment. 
The LOQs for $\mathrm{Fe}, \mathrm{Cu}, \mathrm{Zn}, \mathrm{Mn}$, and $\mathrm{Cr}$ were calculated as $0.53,0.99,0.89,0.23$, and $0.33 \mu \mathrm{g} / \mathrm{kg}$, respectively. The LODs of these essential elements were 0.16, 0.30, 0.27, 0.07 , and $0.10 \mu \mathrm{g} / \mathrm{kg}$, respectively (Table 2 ).

The recoveries of the investigated essential elements at these six spiking levels were presented in Table 2. Repeatability of the essential elements were relative standard deviation $(\mathrm{RSD})<20 \%$ with $\mathrm{n}=3$ at each spiking level.

\section{The concentrations of essential elements in fruits}

The levels of essential elements in different fruits in studied area were demonstrated in Table 3 . The golden plum was a valuable source of $\mathrm{Cr}, \mathrm{Fe}, \mathrm{Mn}$, and $\mathrm{Zn}$ with $6.16 \pm 2.81$, $168.32 \pm 101.96,19.51 \pm 9.98$, and $12.20 \pm 7.63 \mu \mathrm{g} / \mathrm{kg}$, respectively. The highest concentrations of $\mathrm{Cu}$ were observed in grape samples with a mean of $27.91 \pm 14.18 \mu \mathrm{g} / \mathrm{kg}$.

A significant difference in the content of the elements between fruit species $(\mathrm{P}<0.05)$ was noted (Table 3$)$. This could be attributed to many factors, such as different uptake levels and accumulation capacities among fruit species, different $\mathrm{pH}$, organic matter contents, different soil characteristics, the amount of fertilizer used, and irrigation with contaminated wastewater (Duran et al., 2008). In a study conducted in Turkey, the levels of Fe, Cr, and $\mathrm{Mn}$ in golden plum were reported as 41,320 \pm 3800 , $6170 \pm 600$, and $6470 \pm 570 \mu \mathrm{g} / \mathrm{kg}$, respectively. However, in agreement with the result of the current study, they reported that the highest amount of $\mathrm{Cu}(4529 \pm 370 \mu \mathrm{g} /$ $\mathrm{kg})$ and $\mathrm{Cr}(6170 \pm 600 \mu \mathrm{g} / \mathrm{kg})$ were correlated with grape and golden plum, respectively (Duran et al., 2008). The mean concentrations of $5 \pm 0.00 \mu \mathrm{g} / \mathrm{kg}$ for $\mathrm{Cu}$ and $65 \pm$ $40 \mu \mathrm{g} / \mathrm{kg}$ for $\mathrm{Zn}$ in apple and $15 \pm 20 \mu \mathrm{g} / \mathrm{kg}$ for $\mathrm{Cu}$ and $63 \pm 90 \mu \mathrm{g} / \mathrm{kg}$ for $\mathrm{Zn}$ in grape were reported by a study conducted in the northwest of Iran (Ehsani et al., 2015). Besides, based on the Institute of Medicine (IoM), in the United States, the tolerable upper intake level (UL) for adults was determined to be 45,000, 10,000, 40,000, and $11,000 \mu \mathrm{g} /$ day of $\mathrm{Fe}, \mathrm{Cu}, \mathrm{Zn}, \mathrm{Mn}$, respectively (IOM, 2001). The concentrations of the elements in the current investigation were lower or within the safe range.

According to the level of elements in different places and fruits, we can conclude that the highest levels of $\mathrm{Cr}, \mathrm{Fe}$, $\mathrm{Mn}, \mathrm{Zn}$, and $\mathrm{Cu}$ were observed in Khondab plum, while $\mathrm{Cu}$ concentrations were higher in Tafresh. The lowest levels of Fe and Mn were found in Mahallat grape. The lowest levels of $\mathrm{Zn}$ and $\mathrm{Cu}$ were observed in Tafresh and Khondab nectarine, respectively (Table 3 ). These various concentrations of elements in fruits from different regions can be attributed to the type of soil, water, air, fertilizer, and pesticides. As the results show, the concentrations of several elements, for example, $\mathrm{Cu}$ and $\mathrm{Mg}$ in Saveh, are very high compared to the other sampling areas, most likely due to the composition and type of fertilizer used in that area.

Recently, in Iran, the source of contamination of elements is not only industrial pollution and the excessive use of

Table 2. Average recoveries (\%), relative standard deviations (\%), LOD, and LOQ $(\mu \mathrm{g} / \mathrm{kg})$ obtained by ICP-OES analysis at six spiking levels $(n=3)$ in fruit, soil, and water samples.

\begin{tabular}{|c|c|c|c|c|c|}
\hline Metal & Samples & Recovery $(n=18)$ & $\begin{array}{l}\text { Range of RSD } \\
\qquad(n=3)\end{array}$ & LOD & LOQ \\
\hline \multirow[t]{3}{*}{$\mathrm{Cr}$} & Fruits & $113.70 \pm 7.57(100.46-117.79)$ & $5.11-18.91$ & 0.10 & 0.33 \\
\hline & Soil & $96.10 \pm 10.01(86.55-115.28)$ & $5.70-15.82$ & & \\
\hline & Water & $110.06 \pm 4.93(105.45-114.84)$ & $7.34-19.75$ & & \\
\hline \multirow[t]{3}{*}{$\mathrm{Cu}$} & Fruits & $100.34 \pm 8.08(89.68-110.54)$ & $5.70-17.40$ & 0.30 & 0.99 \\
\hline & Soil & $89.68 \pm 16.43(86.07-115.33)$ & $2.80-19.00$ & & \\
\hline & Water & $110.92 \pm 6.99(100.51-119.91)$ & $3.70-14.70$ & & \\
\hline \multirow[t]{3}{*}{$\mathrm{Fe}$} & Fruits & $111.56 \pm 7.83(101.89-120.94)$ & $4.92-19.30$ & 0.16 & 0.53 \\
\hline & Soil & $95.34 \pm 7.33(84.13-103.75)$ & $4.20-18.23$ & & \\
\hline & Water & $109.13 \pm 8.13(99.39-118.64)$ & $3.30-17.80$ & & \\
\hline \multirow[t]{3}{*}{$\mathrm{Mn}$} & Fruits & $101.48 \pm 6.26(90.30-109.28)$ & $6.20-19.30$ & 0.07 & 0.23 \\
\hline & Soil & $88.48 \pm 15.12(74.77-108.76)$ & $5.85-17.25$ & & \\
\hline & Water & $109.85 \pm 5.82(101.71-118.54)$ & $1.72-14.93$ & & \\
\hline \multirow[t]{3}{*}{$\mathrm{Zn}$} & Fruits & $110.70 \pm 8.56(96.71-119.66)$ & $2.80-11.10$ & 0.27 & 0.89 \\
\hline & Soil & $97.25 \pm 12.16(86.08-113.86)$ & $5.90-16.60$ & & \\
\hline & Water & $108.30 \pm 11.84(92.56-119.84)$ & $3.80-14.90$ & & \\
\hline
\end{tabular}




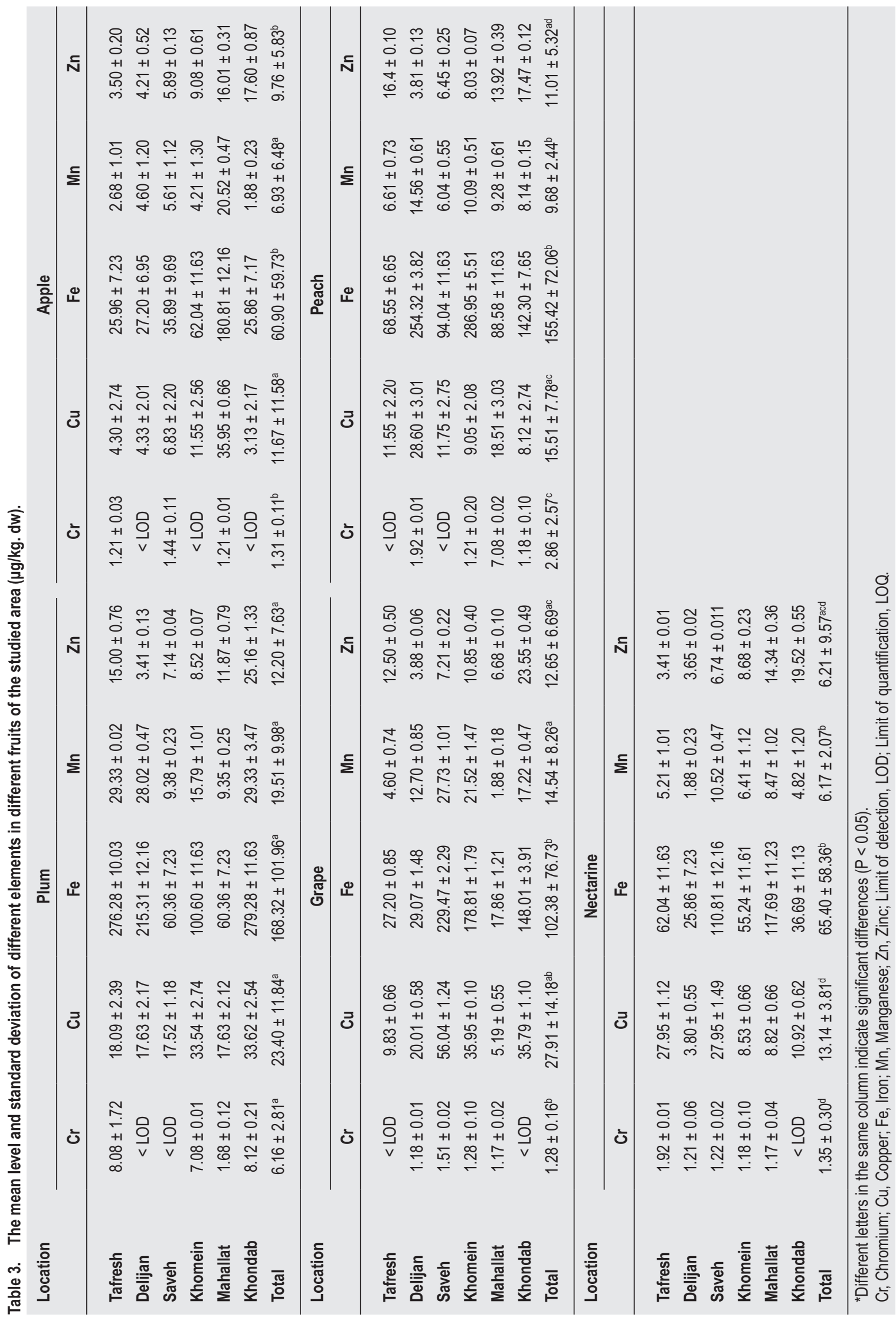


chemical pesticides but also the overuse of manure and other chemical fertilizers in the soil (Hatamikiya et al., 2018). Furthermore, it has been demonstrated that most plants need an adequate amount of elements for healthy growth, and usually in Iran artificial or combined inorganic fertilizers are used to fortify the soil and the plant to provide the necessary essential elements such as $\mathrm{Cu}$ (Maleki and Zarasvand, 2008). Therefore, element contamination may not be only due to industrial contamination. Therefore, attention should be paid to agricultural products even if they are not grown near an industrial area. Moreover, different plant species have different capacities for accumulation (Mirecki et al., 2015). Therefore, another suggestion is to apply optimal programs for cultivating alternative plants with low accumulation capacity near the industrial area. Similarly, a study in India on vegetables showed that $\mathrm{Fe}$ is the most abundant element in fruits, which is also in agreement with the reported results (Kooner et al., 2014).

In the present study, the mean levels of $\mathrm{Cu}$ were $18.34 \pm$ $12.16 \mu \mathrm{g} / \mathrm{kg}$, with the highest levels reported in grape and the lowest in apple. These reports are consistent with the reports of Duran et al. (2008), where mean concentrations of $\mathrm{Cu}$ ranged from 1.68 to $4.52 \mu \mathrm{g} / \mathrm{kg}$. Their study showed that the highest level was observed in black grape while the lowest level was observed in white mulberry (Duran et al., 2008). According to Pipoyan et al. (2019), the farmlands' tailing repositories were the reason for the high $\mathrm{Cu}$ concentration in fruits and vegetables (Pipoyan et al., 2019).

\section{The concentrations in soil and water samples}

The mean concentrations of $\mathrm{Cr}, \mathrm{Cu}, \mathrm{Fe}, \mathrm{Mn}$, and $\mathrm{Zn}$ in the soil were $221.90 \pm 74.30,772.50 \pm 204.70,383306.20 \pm$ $90254.20,13415.00 \pm 3557.10$, and $1787.60 \pm 441.40 \mu \mathrm{g} /$ $\mathrm{kg}$, respectively (Table 4). Maximum permissible concentration (MPA) of Cu, $\mathrm{Zn}$, and $\mathrm{Cr}$ are 30, 200, and $100 \mathrm{mg}$ / $\mathrm{kg}$, respectively (Sudhakaran et al., 2018). Soil samples of the Khomein contained the highest levels of $\mathrm{Cr}$ and $\mathrm{Fe}$
$(353.46 \pm 8.62$ and $495074.00 \pm 251.63 \mu \mathrm{g} / \mathrm{kg}$, respectively) while soil samples from Tafresh and Delijan contained the lowest level of these elements $(164.69 \pm 8.12$ and $233,870 \pm 252 \mu \mathrm{g} / \mathrm{kg}$, respectively). The highest levels of $\mathrm{Cu}, \mathrm{Mn}$, and $\mathrm{Zn}$ in soil samples were observed in Khondab, Tafresh, and Delijan, respectively (974.42 \pm $11.23,16993.66 \pm 84.27$ and $2470.11 \pm 2.01 \mu \mathrm{g} / \mathrm{kg}$ ). At the same time, soil samples from Saveh contained the lowest level of these elements $(489.19 \pm 12.01,9042.14 \pm 82.32$, and $1024.53 \pm 1.73 \mu \mathrm{g} / \mathrm{kg}$, respectively). This dispersion could be due to the type of soil in different geographic regions and the different agricultural processes in the studied areas. The use of soil fertilizers is a significant factor because the use of the same type of fertilizer by all farmers in one area ultimately leads to homogeneity of certain elements (e.g., Fe, Mn, and $\mathrm{Zn}$ in water samples of Khomein) in the soils of that area.

In a similar investigation regarding soils collected from different farms in China, the concentrations of $\mathrm{Cr}, \mathrm{Cu}$, and $\mathrm{Zn}$ were $58,870,31,710$, and $117,720 \mu \mathrm{g} / \mathrm{kg}$, respectively (Wei and Yang, 2010). Also, Mico et al. (2006) reported that the concentrations of $\mathrm{Fe}, \mathrm{Mn}, \mathrm{Zn}, \mathrm{Cr}$, and $\mathrm{Cu}$ in Spanish agricultural soils were 13,608,000, 295,000, $53,000,27,000$, and 23,000 $\mu \mathrm{g} / \mathrm{kg}$, respectively (Micó et al., 2006).

Ennaji et al. (2020) reported that the mean concentrations of $\mathrm{Cd}, \mathrm{Cr}, \mathrm{Cu}$, and $\mathrm{Zn}$ in the agricultural soil of the northeast area of Tadla plain, Morocco, were 32.72, 138.10 , and $162.11 \mathrm{mg} / \mathrm{kg}$, respectively. Also, they stated that these values are higher than the acceptable thresholds of the World Health Organization (WHO) and the Food and Agriculture Organization (FAO) (Ennaji et al., 2020). Fan et al. (2020) showed that the concentrations of $\mathrm{Cr}$ and $\mathrm{Zn}$ in all samples collected from an agriculturally dominated region in eastern China were lower than the risk-screening values (Fan et al., 2020). Varol et al. (2020) studied the content of trace elements in soils of Harran Plain, Turkey, and concluded that $\mathrm{Cu}$ and Cr's carcinogenic risk values were within the acceptable risk range (Varol et al., 2020).

Table 4. The minimum, maximum, and mean \pm SD concentration of the studied elements in the experimented soil and water ( $\mu \mathrm{g} / \mathrm{kg}$ or liter).

\begin{tabular}{rlrccrr} 
& & Cr & Cu & Fe & Mn & Zn \\
\hline \multirow{2}{*}{ Water } & Min & $<$ LOD & $<$ LOD & 54.80 & 363.90 & 68.00 \\
& Max & $<$ LOD & $<$ LOD & 2982.90 & 620.00 & 641.90 \\
& Mean \pm SD & $<$ LOD & $<$ LOD & $1316 \pm 1108$ & $483.80 \pm 112.90$ & $327.90 \pm 182.11$ \\
Soil & Min & 156.30 & 479.10 & 233618.40 & 8949.70 & 1023.20 \\
& Max & 362.30 & 986.50 & 495325.60 & 17066.10 & 2472.10 \\
& Mean \pm SD & $221.90 \pm 74.31$ & $772.50 \pm 204.72$ & $383306.20 \pm 90254.22$ & $13415.00 \pm 3557.11$ & $1787.60 \pm 441.42$ \\
\hline
\end{tabular}

Limit of detection, LOD; Cr, Chromium ; Cu, Copper ; Fe, Iron ; Mn, Manganese ; Zn, Zinc; Min, minimum; Max, maximum. 
Table 5. The total mean value of TF and RfD of elements $(\mu \mathrm{g} / \mathrm{kg}-\mathrm{d})$.

\begin{tabular}{lccccc} 
& $\mathrm{Cr}$ & $\mathrm{Cu}$ & $\mathrm{Fe}$ & $\mathrm{Mn}$ & $\mathrm{Zn}$ \\
\hline $\mathrm{TF}$ & $0.0120 \pm 0.0090$ & $0.0220 \pm 0.0090$ & $0.0003 \pm 0.0001$ & $0.0010 \pm 0.0002$ & $0.009 \pm 0.002$ \\
$\mathrm{RfD}^{*}$ & 3 & 40 & 700 & 140 & 300 \\
\hline \multirow{2}{*}{ Reference dose. } & & & \\
TF, transfer factor; Cr, Chromium ; Cu, Copper ; Fe, Iron ; Mn, Manganese ; Zn, Zinc.
\end{tabular}

The concentrations of these elements are higher than the results of the present study. Elements like Fe and Mn can be influenced by the available microorganisms in the soil activity to extend their bioavailability and facilitate their uptake through the root of the plant (Wilberforce, 2016). Metal solubility in the soil is another factor that differs between metals ( $\mathrm{Xu}$ et al., 2013). Besides, the composition of the soil (clay, organic material, and $\mathrm{pH}$ ) alters $\mathrm{Zn}$ bioavailability, which causes a wide range of $\mathrm{Zn}$ concentrations in different soils (Noulas et al., 2018).

Regarding water samples, the concentrations of $\mathrm{Cr}, \mathrm{Cu}$, $\mathrm{Fe}, \mathrm{Mn}$, and $\mathrm{Zn}$ were in the ranges of $<\mathrm{LOD},<\mathrm{LOD}$, $1316 \pm 1108,483.80 \pm 112.90$, and $327.90 \pm 182.10 \mu \mathrm{g} / \mathrm{l}$, respectively (Table 4 ). The rank order of average concentrations of the elements in the investigated soil and water samples was $\mathrm{Fe}>\mathrm{Mn}>\mathrm{Zn}>\mathrm{Cu}>\mathrm{Cr}$. The highest Fe, $\mathrm{Mn}$, and $\mathrm{Zn}$ concentrations in the water were observed in Khomein, while the lowest concentrations of these elements were found in Saveh, Mahallat, and Saveh, respectively.

\section{TF of the essential elements in fruits}

The TF calculated of $\mathrm{Cr}, \mathrm{Cu}, \mathrm{Fe}, \mathrm{Mn}$, and $\mathrm{Zn}$ in five fruits species from the surrounded soils were $0.01 \pm 0.01,0.02 \pm$ $0.01,0.0003 \pm 0.0001,0.0010 \pm 0.0002$ and $0.009 \pm 0.002$, respectively (Table 5 ). Metals could have different compositions in the soil, such as carbonate, oxide, or organic, which could affect their uptake by plants (Fijałkowski et al., 2012). There is no correlation between the amount of elements in the water and soil of one area and the extent of elements in the fruits of the same area. The high or low levels of water and soil elements did not significantly affect their concentrations in cultivated fruits, which is also shown by the TF result.

According to TF index description, TF $<1$ means lower absorption of elements from the soil (Ali et al., 2019). The reported TF results indicate that fruits cannot accumulate high levels of these elements from the soil. However, it has been reported that even if the level of elements such as $\mathrm{Cr}$ in the soil is in the WHO standard range, some plants uptake more concentrations, and the accumulation level is at a dangerous level (Maleki et al., 2014). According to the finding of a previous investigation, when TF in samples is higher than 0.5, the plant will have a higher potency of metal contamination in the environment (Khan et al., 2009; Mirecki et al., 2015). Heidari et al. (2014) stated that fruit trees (involving apple trees) near industrial sites accumulate a dangerous amount of elements like Cr. Moreover, considering identical soil conditions, the accumulation of the elements varies in different parts of the plants. Also, it differs with regard to the type of plant species, and it has been shown that the order of accumulation in edible plants is: leaf vegetables $>$ fruit vegetables $>$ root vegetables $>$ grains (Mirecki et al., 2015). The current study focused on fruit tissues only; therefore, attention should be paid to the other parts of plants (if they are edible or are used during the food processing) or other types of crops or vegetables, especially their leafy part is cultivated in a polluted area.

\section{Risk assessment}

\section{Noncarcinogenic and carcinogenic risks}

THQ (percentile 95\%) in adults due to intake of $\mathrm{Fe}, \mathrm{Cu}, \mathrm{Zn}$, $\mathrm{Mn}$, and $\mathrm{Cr}$ through consumption of fruits were $1.24 \mathrm{E}-3$, $1.85 \mathrm{E}-3,4.80 \mathrm{E}-8,7.69 \mathrm{E}-8$, and $1.21 \mathrm{E}-5$, respectively (Figure $2 \mathrm{~A}-\mathrm{E}$ ). Also THQ (percentile 95\%) in children for the same elements was 2.23E-3, 1.45E-7, 2.20E-5, 3.37E-5, and $9.02 \mathrm{E}-7$ respectively (Figure $3 \mathrm{~A}-\mathrm{E}$ ). The rank order of elements based on their THQ in adults and children was $\mathrm{Cr}>\mathrm{Cu}>\mathrm{Fe}>\mathrm{Mn}>\mathrm{Zn}$. THQ of $\mathrm{Cr}$ was higher than other essential elements because of its lower RfD (EPA, 2012). THQ in children was 1.87 times higher than adults because they have lower body weight (Abtahi et al., 2017; Adel et al., 2016; Fakhri et al., 2017).

The rank order of elements based on TTHQ was $\mathrm{Cr}$ $(44.34 \%)>\mathrm{Cu}(34.07)>\mathrm{Fe}(11.77 \%)>\mathrm{Mn}(6.03 \%)>\mathrm{Zn}$ $(3.79 \%)$ (Figure 4). TTHQ (Percentile 95\%) due to all elements ( $\mathrm{Cr}, \mathrm{Cu}, \mathrm{Fe}, \mathrm{Mn}$, and $\mathrm{Zn}$ ) in adults and children was 5.524E-07 and 1.0334E-06, respectively (Figure 4), which was lower than 1. THQ and TTHQ in both adults and children were $<1$ because of the low ingestion rate of fruits and the low concentrations of essential elements 


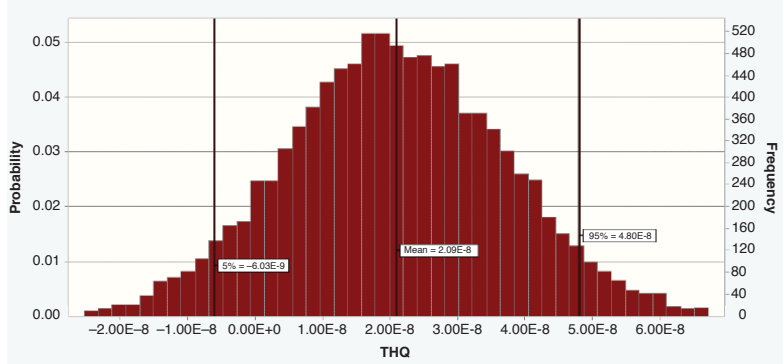

(a)

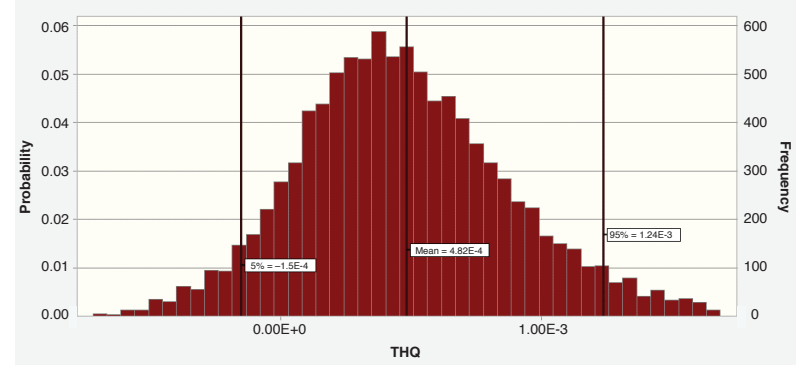

(c)

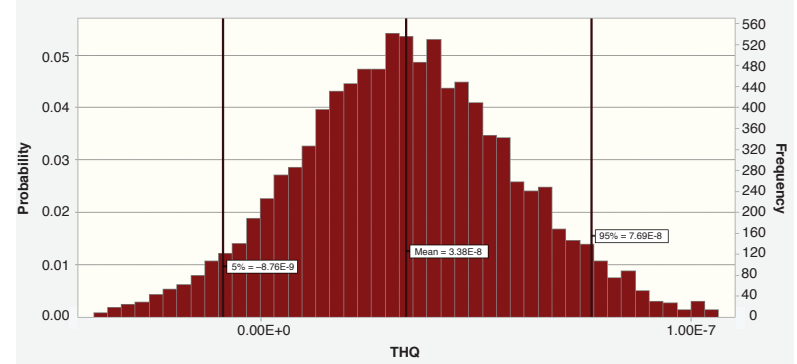

(b)

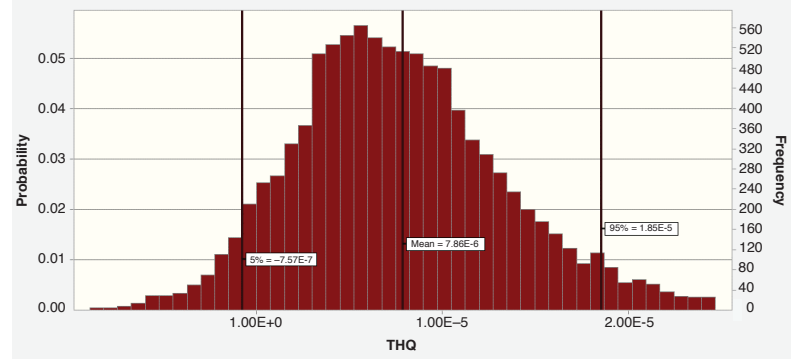

(d)

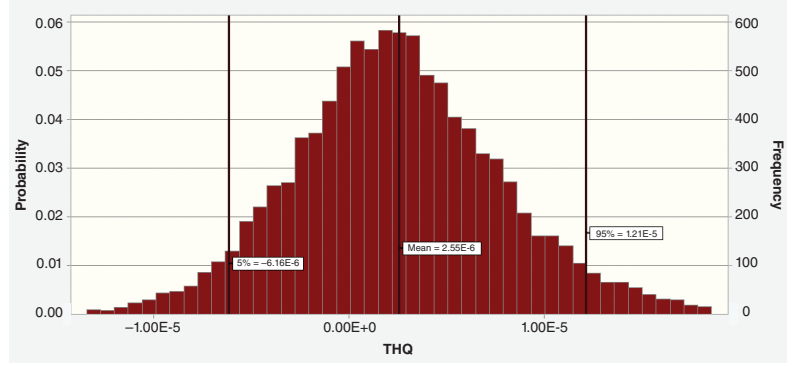

(e)

Figure 2. Target hazard quotient (THQ) in adults due to ingestion fruits content of $\mathrm{Zn}(\mathrm{A}), \mathrm{B}(\mathrm{Mn}), \mathrm{C}(\mathrm{Fe}), \mathrm{D}(\mathrm{Cu})$, and $\mathrm{E}(\mathrm{Cr})$ via fruits consumption.

(Abtahi et al., 2017; Adel et al., 2016; Fakhri et al., 2017; Statista, 2013). Therefore, populations are not at a considerable noncarcinogenic risk of essential elements in fruits.

In Pipoyan et al. 2019 study, the THQ for the Mo level in cabbage exceeded 1, with 1.65 for males and 1.6 for females, indicating a health risk in consuming cabbage. However, for other fruits and veggies, THQ was $<1$, but they could substantially contribute to TTHQ (Pipoyan et al., 2019). Abdelkareem et al. (2018) reported that the levels of $\mathrm{Zn}, \mathrm{Cr}, \mathrm{Cu}, \mathrm{Fe}$, and $\mathrm{Mn}$ in different fruits in Saudi Arabia were $\sim 2,850,1,150,100$, and $10 \mu \mathrm{g} / \mathrm{kg}$, respectively, which were lower than LOD and safe for consumers in terms of the amount of these elements (Abdelkareem et al., 2018). Qureshi et al. 2016 reported high levels of $\mathrm{Cu}$, $\mathrm{Cr}$, and $\mathrm{Zn}$ in some vegetables in the United Arab Emirates; however, it was lower than the safety standards of the WHO and the European Union (Qureshi et al., 2016).
The findings of the present study demonstrate that the fruit samples used by local people in Markazi province are safe and without any health risk to consumers.

\section{Nutritional assessment}

Grembecka et al. (2013) investigated micro and macro elements among different fruits. Based in their findings, Fe has the highest concentration $(156 \mu \mathrm{g} / \mathrm{kg}$ in grapefruit), followed by Mn and Zn, (Grembecka and Szefer, 2013). It was in sync with the finding of our study. Basha et al. (2014) studied the level of some elements in fruits and vegetables in India. The range of $\mathrm{Mn}, \mathrm{Fe}, \mathrm{Ni}, \mathrm{Cu}$, and $\mathrm{Zn}$ was reported as $300-8,100 ; 6,500-126,300 ; 100-4,100$; $300-3,200$; and $100-19,700 \mu \mathrm{g} / \mathrm{kg}$, respectively, and the trend of the measured essential elements was reported as $\mathrm{Fe}>\mathrm{Al}>\mathrm{Zn}>\mathrm{Mn}>\mathrm{Cr}>\mathrm{Cu}>\mathrm{Pb}>\mathrm{Ni}>\mathrm{Co}>\mathrm{V}>\mathrm{Cd}>$ $\mathrm{Be}>\mathrm{U}$, which is similar to this study. They also reported 


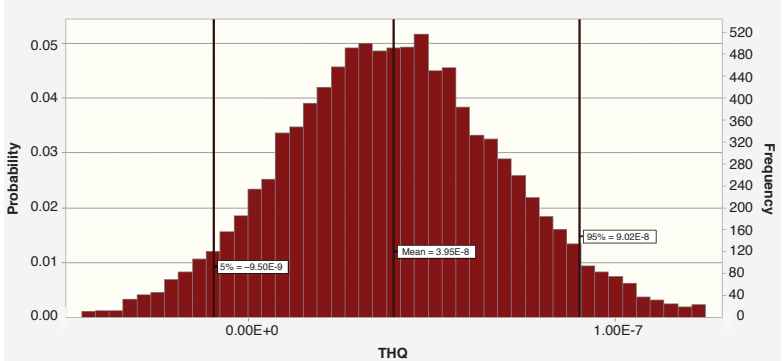

(a)

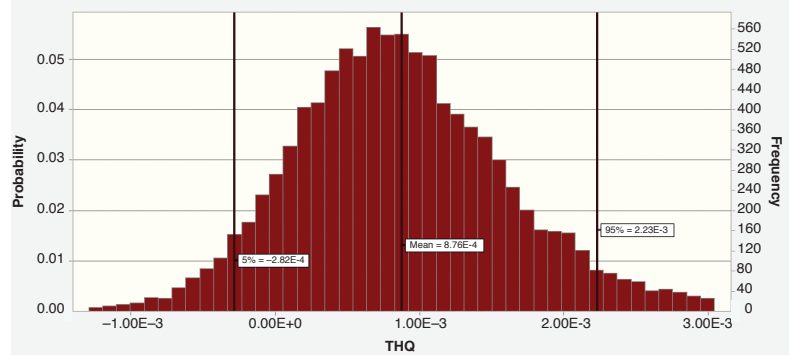

(c)

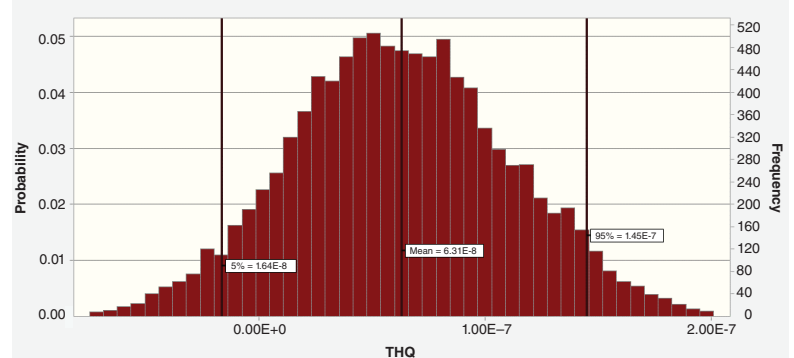

(b)

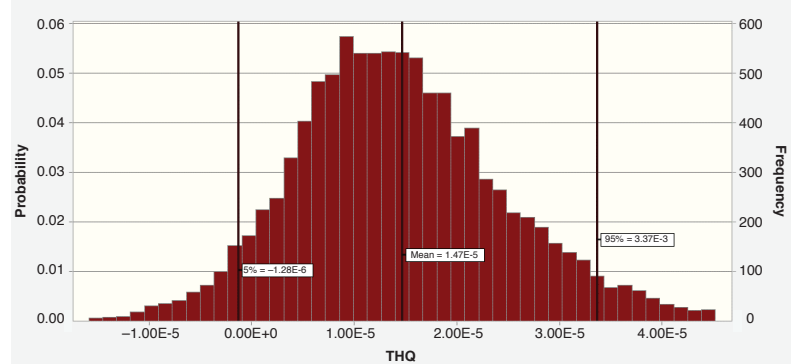

(d)

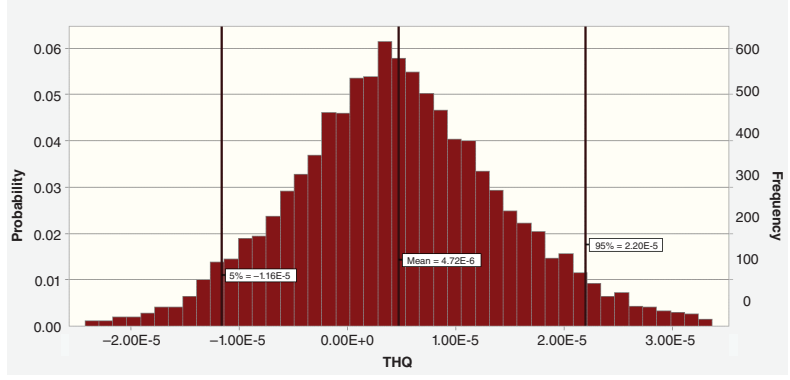

(e)

Figure 3. Target hazard quotient (THQ) in children due to ingestion fruits content of $\mathrm{Zn}(\mathrm{A}), \mathrm{B}(\mathrm{Mn}), \mathrm{C}(\mathrm{Fe}), \mathrm{D}(\mathrm{Cu})$, and $\mathrm{E}(\mathrm{Cr})$ via fruits consumption.

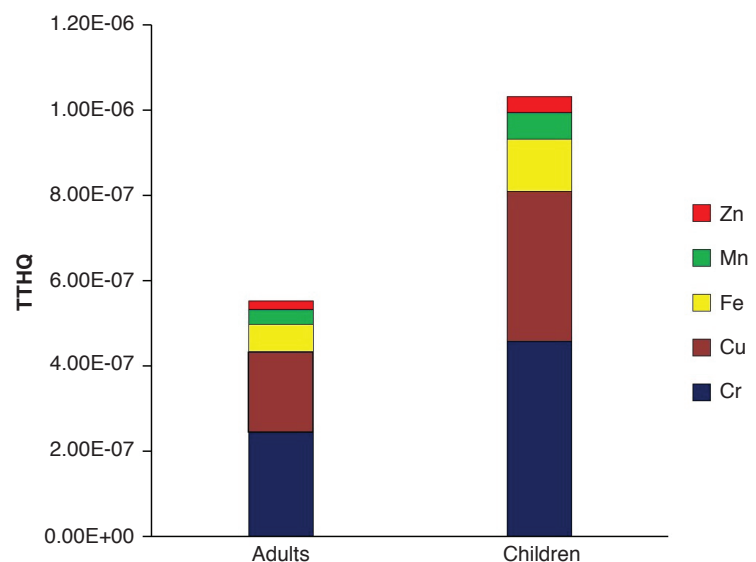

Figure 4. Total target hazard quotient (TTHQ) in adults and children due to ingestion fruits content of $\mathrm{Zn}, \mathrm{Mn}, \mathrm{Fe}, \mathrm{Cu}$, and $\mathrm{Cr}$. that the daily intake $\mathrm{Zn}, \mathrm{Fe}, \mathrm{Mn}$, and $\mathrm{Cu}$ was $600,3,500$, 200, and $100 \mu \mathrm{g} / \mathrm{day}$, respectively (Basha et al., 2014).

The findings showed that the golden plum is a valuable source of $\mathrm{Fe}, \mathrm{Mn}$, and $\mathrm{Cr}$. In this regard, based on the report of Duran et al. (2008), the highest concentration of Fe was detected in the apricot with $64.10 \mu \mathrm{g} / \mathrm{kg}$. They also marked the golden plum as a rich source of Fe (Duran et al., 2008). Also, Sattar et al. (1989) demonstrated that the Fe concentration in dried fruits of Pakistan was in the range 19-45 $\mu \mathrm{g} / \mathrm{kg}$ dry weight (Sattar et al., 1989), while according to Zahoor et al. (2003), the content of this element in fruits of Pakistan was 3,890-40,700 $\mu \mathrm{g} / \mathrm{kg}$ wet weight (Zahoor et al., 2003).

\section{Conclusions}

Elements like $\mathrm{Fe}, \mathrm{Cu}, \mathrm{Zn}$, and $\mathrm{Mn}$ quickly enter into food commodities from various sources of the ecosystem. 
While they are essential for humans health, in a exceed concentration can resulted in some adverse effects. In this study, concentrations of $\mathrm{Fe}, \mathrm{Zn}, \mathrm{Cu}, \mathrm{Mn}$, and $\mathrm{Cr}$ $(\mu \mathrm{g} / \mathrm{kg} \mathrm{FW})$ in five highly consumed fruits, namely, peach, apple, grape, nectarine, and golden plum, were determined. According to the results, the highest concentrations of $\mathrm{Fe}, \mathrm{Mn}$, and $\mathrm{Cr}$ were found in golden plum and that of $\mathrm{Cu}$ and $\mathrm{Zn}$ were found in the grape, which showed that the golden plum has a high ability to accumulate essential elements and is considered a rich source of elements among fruits. The concentrations of the studied elements were lower than the standards, which mean that the consumption of fruits is safe in terms of the amounts of these elements. The probabilistic health risk revealed that adults and children are not at noncarcinogenic risk $(95 \% \mathrm{THQ}$ and TTHQ $<1)$. Regarding the ability of elements to accumulate among plant or TF, it could be stated that fruits have a low ability to uptake and accumulate the toxic level of elements in their tissues. The present study demonstrates that these fruits are a valuable diary resource of essential elements. Among them, golden plum and grape may provide a significant daily intake dose of these elements.

\section{Conflict of interest}

The authors declare that they have no conflict of interest.

\section{References}

Abbaspour, N., Hurrell, R. and Kelishadi, R., 2014. Review on iron and its importance for human health. Journal of Research in Medical Sciences: The Official Journal of Isfahan University of Medical Sciences 19: 164.

Abdelkareem, A.A.M., Mahmoud, M.H.H., Ali, D.M.H., Khalid, M.A.A., Alotaibi, S.H.M. and Elsheikh, MAA., 2018. Essential and toxic heavy metals status in some fruits from Turaba District (Saudi Arabia). Health Risk Assessment. Science, Technology \& Public Policy 2: 26.

Aberournand, A., 2012. Energy and nutrient intake and food diets among Iranian University students. American Journal of Food Technology 7: 880-885. https://doi.org/10.3923/ ajft.2012.380.385

Abtahi, M., Fakhri, Y., Oliveri Conti, G., Keramati, H., Zandsalimi, Y., Bahmani, Z., Hosseini Pouya, R., Sarkhosh, M., Moradi, B. and Amanidaz, N., 2017. Heavy metals (As, Cr, Pb, Cd, and Ni) concentrations in rice (Oryza sativa) from Iran and associated risk assessment: a systematic review. Toxin Reviews 36: 331-341. https://doi.org/10.1080/15569543.2017.1354307

Adel, M., Dadar, M., Fakhri, Y., Oliveri Conti, G. and Ferrante, M., 2016. Heavy metal concentration in muscle of pike (Esox lucius Linnaeus, 1758) from Anzali international wetland, southwest of the Caspian Sea and their consumption risk assessment. Toxin Reviews 35: 217-223. https://doi.org/10.1080/15569543.2016.1223694
Akbari, M., Moosazadeh, M., Tabrizi, R., Khatibi, S.R., Khodadost, M., Heydari, S.T., Tahami, A.N. and Lankarani, K.B., 2017. Estimation of iron deficiency anemia in Iranian children and adolescents: a systematic review and meta-analysis. Hematology (Amsterdam, Netherlands) 22: 231-239. https:// doi.org/10.1080/10245332.2016.1240933

Ali, A.S.M., Ahmed, H.A.M., Emara, H.A.E.-A., Janjua, M.N. and Alhafez, N., 2019. Estimation and bio-availability of toxic metals between soils and plants. Polish Journal of Environmental Studies 28: 15-24. https://doi.org/10.15244/pjoes/81690

Araújo, S., Matos, C., Correia, E. and Antunes, M., 2019. Evaluation of phytochemicals content, antioxidant activity and mineral composition of selected edible flowers. Quality Assurance and Safety of Crops \& Foods 11: 471-478. https://doi.org/10.3920/QAS2018.1497

Bagdatlioglu, N., Nergiz, C. and Ergonul, P.G., 2010. Heavy metal levels in leafy vegetables and some selected fruits. Journal für Verbraucherschutz und Lebensmittelsicherheit 5: 421-428. https://doi.org/10.1007/s00003-010-0594-y

Bailey, R.L., West Jr, K.P. and Black, R.E., 2015. The epidemiology of global micronutrient deficiencies. Annals of Nutrition and Metabolism 66: 22-33. https://doi.org/10.1159/000371618

Basha, A.M., Yasovardhan, N., Satyanarayana, S.V., Reddy, G.V.S. and Kumar, A.V., 2014. Trace metals in vegetables and fruits cultivated around the surroundings of Tummalapalle uranium mining site, Andhra Pradesh, India. Toxicology Reports 1: 505-512. https://doi.org/10.1016/j.toxrep.2014.07.011

Bost, M., Houdart, S., Oberli, M., Kalonji, E., Huneau, J.-F. and Margaritis, I., 2016. Dietary copper and human health: current evidence and unresolved issues. Journal of Trace Elements in Medicine and Biology 35: 107-115. https://doi.org/10.1016/j. jtemb.2016.02.006

Brown, K.H., Wuehler, S.E. and Peerson, J.M., 2001. The importance of zinc in human nutrition and estimation of the global prevalence of zinc deficiency. Food and Nutrition Bulletin 22: 113125. https://doi.org/10.1177/156482650102200201

Chen, M.-J., Hsu, H.-T., Lin, C.-L. and Ju, W.-Y., 2012. A statistical regression model for the estimation of acrylamide concentrations in French fries for excess lifetime cancer risk assessment. Food and Chemical Toxicology 50: 3867-3876. https://doi. org/10.1016/j.fct.2012.07.010

Clarkson, P.M., 1991. Nutritional ergogenic aids: chromium, exercise, and muscle mass. International Journal of Sport Nutrition 1: 289-293. https://doi.org/10.1123/ijsn.1.3.289

Dadar, M., Adel, M., Nasrollahzadeh Saravi, H. and Fakhri, Y., 2017. Trace element concentration and its risk assessment in common kilka (Clupeonella cultriventris caspia Bordin, 1904) from southern basin of Caspian Sea. Toxin Reviews 36: 222-227. https://doi.org/10.1080/15569543.2016.1274762

Derakhshan, Z., Faramarzian, M., Mahvi, A., Hosseini, M. and Miri, M., 2016. Assessment of heavy metals residue in edible vegetables distributed in Shiraz, Iran. Journal of Food Quality and Hazards Control 3: 25-29.

Duran, A., Tuzen, M. and Soylak, M., 2008. Trace element levels in some dried fruit samples from Turkey. International Journal of Food Sciences and Nutrition 59: 581-589. https://doi. org/10.1080/13561820701507910 
Ehsani, A., Ebadi, A., Shariatifar, N., Mojaddar, N. and Azimi, M., 2015. Assessment of some heavy metals in fruits and vegetables collected from markets in Urmia. International Journal of Current Science 15S: 78-84

Ennaji, W., Barakat, A., El Baghdadi, M. and Rais, J., 2020. Heavy metal contamination in agricultural soil and ecological risk assessment in the northeast area of Tadla plain, Morocco. Journal of Sedimentary Environments 5: 307-320. https://doi. org/10.1007/s43217-020-00020-9

EPA, 2012. Quantitative risk assessment calculations. Sustainable futures/P2 framework manual 2012 EPA-748-B12-001 13. Quantitative Risk Assessment Calculations 13: 1-11.

EPA, 2017. Regional screening level (RSL) summary table (TR=1E-06, HQ=1) November 2017. regional screening levels (RSLs) - generic tables. Available at: https://www.epa.gov/risk/ regional-screening-levels-rsls-generic-tables

Fakhri, Y., Mousavi Khaneghah, A., Hadiani, M.R., Keramati, H., Hosseini Pouya, R., Moradi, B. and da Silva, B.S., 2017. Noncarcinogenic risk assessment induced by heavy metals content of the bottled water in Iran. Toxin Reviews 36: 313-321. https:// doi.org/10.1080/15569543.2017.1358747

Fan, M., Margenot, A.J., Zhang, H., Lal, R., Wu, J., Wu, P., Chen, F. and Gao, C., 2020. Distribution and source identification of potentially toxic elements in agricultural soils through high-resolution sampling. Environmental Pollution 263: 114527. https:// doi.org/10.1016/j.envpol.2020.114527

Fathabad, A.E., Shariatifar, N., Moazzen, M., Nazmara, S., Fakhri, Y., Alimohammadi, M., Azari, A. and Khaneghah, A.M., 2018. Determination of heavy metal content of processed fruit products from Tehran's market using ICP-OES: a risk assessment study. Food and Cchemical Toxicology 115: 436-446. https:// doi.org/10.1016/j.fct.2018.03.044

Fijałkowski, K., Kacprzak, M., Grobelak, A. and Placek, A., 2012. The influence of selected soil parameters on the mobility of heavy metals in soils. Inżynieria i Ochrona środowiska 15: 81-92.

Ghasemidehkordi, B., Malekirad, A.A., Nazem, H., Fazilati, M., Salavati, H. and Rezaei, M., 2018a. Arsenic and boron levels in irrigation water, soil, and green leafy vegetables. International Journal of Vegetable Science 24: 115-121.

Ghasemidehkordi, B., Malekirad, A.A., Nazem, H., Fazilati, M., Salavati, H., Shariatifar, N., Rezaei, M., Fakhri, Y. and Khaneghah, A.M., 2018b. Concentration of lead and mercury in collected vegetables and herbs from Markazi province, Iran: a non-carcinogenic risk assessment. Food and Chemical Toxicology 113: 204-210. https://doi.org/10.1080/19315260.2017.1356896

Grembecka, M. and Szefer, P., 2013. Comparative assessment of essential and heavy metals in fruits from different geographical origins. Environmental Monitoring and Assessment 185: 91399160. https://doi.org/10.1007/s10661-013-3242-z

Hashemi, M., Salehi, T., Aminzare, M., Raeisi, M. and Afshari, A., 2017. Contamination of toxic heavy metals in various foods in Iran: a review. Journal of Pharmaceutical Sciences and Research 9: 1692-1697.

Hatamikiya, M., Dorosti, N. and Mahnaz, Z., 2018. A survey of sampling of heavy metals (lead, cadmium, copper, nickel and mercury) in some cultivated vegetables in Khoramabad city and Aleshtar, Summer 2017. Yafteh 20: 1-12.

Heidari, F., Hosseini, S.M. and Bahramifar, N., 2014. Accumulation of heavy metals in soil, leaf and fruit of, Malus domestica, Elaeagnus angustifolia and Pyrus communis trees around a Zinc Factory in Zanjan, Iran. Journal of Biodiversity and Ecological Sciences 4: 15-28.

Horning, K.J., Caito, S.W., Tipps, K.G., Bowman, A.B. and Aschner, M., 2015. Manganese is essential for neuronal health. Annual Review of Nutrition 35: 71-108. https://doi.org/10.1146/ annurev-nutr-071714-034419

IOM, 2001. Dietary reference intakes for vitamin A, vitamin K, arsenic, boron, chromium, copper, iodine, iron, manganese, molybdenum, nickel, silicon, vanadium, and zinc. The National Academies Press, Washington, DC. https://doi. org/10.17226/10026

Khan, S., Farooq, R., Shahbaz, S., Khan, M.A. and Sadique, M., 2009. Health risk assessment of heavy metals for population via consumption of vegetables. World Applied Sciences Journal 6: 1602-1606.

Kooner, R., Mahajan, B. and Dhillon, W., 2014. Heavy metal contamination in vegetables, fruits, soil and water-a critical review. International Journal of Agriculture, Environment and Biotechnology 7: 603. https://doi. org/10.5958/2230-732X.2014.01365.5

Korkmaz, C., Ay, Ö., Çolakfakığlu, C. and Erdem, C., 2019a. Heavy metal levels in some edible crustacean and mollusk species marketed in Mersin. Thalassas: An International Journal of Marine Sciences 35: 65-71. https://doi.org/10.1007/s41208-018-0086-X

Korkmaz, C., Ay, Ö., Ersoysal, Y., Köroğlu, M.A. and Erdem, C., 2019b. Heavy metal levels in muscle tissues of some fish species caught from north-east Mediterranean: Evaluation of their effects on human health. Journal of Food Composition and Analysis 81: 1-9. https://doi.org/10.1016/j.jfca.2019.04.005

Lato, A., Radulov, I., Berbecea, A., Lato, K. and Crista, F., 2012. The transfer factor of metals in soil-plant system. Research Journal of Agricultural Science 44: 67-72.

Li, F.K., Gong, A.J., Qiu, L.N., Zhang, W.W., Li, J.R., Liu, Y., Li, J.D., Gao, G. and Yuan, X.T., 2019. Determination of trace rare earth elements in fruits by microwave digestion coupled with inductively coupled plasma optical emission spectrometry. Microchemical Journal 147: 93-101.

Maleki, A., Amini, H., Nazmara, S., Zandi, S. and Mahvi, A.H., 2014. Spatial distribution of heavy metals in soil, water, and vegetables of farms in Sanandaj, Kurdistan, Iran. Journal of Environmental Health Science and Engineering 12: 136. https:// doi.org/10.1186/s40201-014-0136-0

Maleki, A. and Zarasvand, M.A., 2008. Heavy metals in selected edible vegetables and estimation of their daily intake in Sanandaj, Iran. Southeast Asian Journal of Tropical Medicine and Public Health 39: 335.

McArdle, H.J. and Ashworth, C.J., 1999. Micronutrients in fetal growth and development. British Medical Bulletin 55: 499-510. https://doi.org/10.1258/0007142991902574.

Micó, C., Recatalá, L., Peris, M. and Sánchez, J., 2006. Assessing heavy metal sources in agricultural soils of an European 
Mediterranean area by multivariate analysis. Chemosphere 65: 863-872. https://doi.org/10.1016/j.chemosphere.2006.03.016

Mirecki, N., Agic, R., Sunic, L., Milenkovic, L. and Ilic, S., 2015. Transfer factor as indicator of heavy metals content in plants. Fresenius Environmental Bulletin 24: 4212-4219.

Noulas, C., Tziouvalekas, M. and Karyotis, T., 2018. Zinc in soils, water and food crops. Journal of Trace Elements in Medicine and Biology 49: 252-260. https://doi.org/10.1016/j. jtemb.2018.02.009

Pipoyan, D., Beglaryan, M., Stepanyan, S. and Merendino, N., 2019. Dietary exposure assessment of potentially toxic trace elements in fruits and vegetables sold in town of Kapan, Armenia. Biological Trace Element Research 190: 234-241. https://doi. org/10.1007/s12011-018-1522-8

Prakash, D., Upadhyay, G., Gupta, C., Pushpangadan, P. and Singh, K., 2012. Antioxidant and free radical scavenging activities of some promising wild edible fruits. International Food Research Journal 19: 1109-1116.

Prohaska, J.R. and Lukasewycz, O.A., 1990. Effects of copper deficiency on the immune system, antioxidant nutrients and immune functions. Springer, Boston, pp. 123-143.

Qu, C.-S., Ma, Z.-W., Yang, J., Liu, Y., Bi, J. and Huang, L., 2012. Human exposure pathways of heavy metals in a lead-zinc mining area, Jiangsu Province, China. PLoS One 7: e46793. https:// doi.org/10.1371/journal.pone.0046793

Qureshi, A.S., Hussain, M.I., Ismail, S. and Khan, Q.M., 2016. Evaluating heavy metal accumulation and potential health risks in vegetables irrigated with treated wastewater. Chemosphere 163: 54-61. https://doi.org/10.1016/j. chemosphere.2016.07.073

Rezaei, M., Farahani, S., Karimi, F., Eshghi, N., Ghasemikhah, R., Abbasi, A., Mohammadpourfard, I. and Jafari, M.J.T.R., 2016. Essential elements content of hen egg-white in Markazi province (Iran). Toxin Reviews 35: 29-32. https://doi.org/10.1080/1 5569543.2016.1180304

Rezaei, M., Shariatifar, N., Shoeibi, S., Ahmadi, M.A. and Khaniki, G.J., 2017. Simultaneous determination of residue from 58 pesticides in the wheat flour consumed in Tehran, Iran by GC/MS. Iranian Journal of Pharmaceutical Research 16: 1048.

Ru, Q.-M., Feng, Q. and He, J.-Z., 2013. Risk assessment of heavy metals in honey consumed in Zhejiang province, southeastern China. Food and Chemical Toxicology 53: 256-262. https://doi. org/10.1016/j.fct.2012.12.015

Sajib, M., Jahan, S., Islam, M., Khan, T. and Saha, B., 2014. Nutritional evaluation and heavy metals content of selected tropical fruits in Bangladesh. International Food Research Journal 21: 609.

Sattar, A., Wahid, M. and Durrani, S.K., 1989. Concentration of selected heavy metals in spices, dry fruits and plant nuts. Plant Foods for Human Nutrition 39: 279-286. https://doi. org/10.1007/BF01091938

Scheinberg, I.H. and Sternlieb, I.J.T.A.j.o.c.n., 1996. Wilson disease and idiopathic copper toxicosis. The American journal of clinical nutrition 63: 842S-845S. https://doi.org/10.1093/ ajcn/63.5.842
Shahsavani, A., Fakhri, Y., Ferrante, M., Keramati, H., Zandsalimi, Y., Bay, A., Hosseini Pouya, S.R., Moradi, B., Bahmani, Z. and Mousavi Khaneghah, A., 2017. Risk assessment of heavy metals bioaccumulation: fished shrimps from the Persian Gulf. Toxin Reviews 36: 322-330. https://doi.org/10.1080/15569543.2017.1 312451

Shakya, P.R. and Khwaounjoo, N.M., 2013. Heavy metal contamination in green leafy vegetables collected from different market sites of Kathmandu and their associated health risks. Scientific World 11: 37-42. https://doi.org/10.3126/sw.v11i11.8550

Shi, W., Zhang, F., Zhang, X., Su, G., Wei, S., Liu, H., Cheng, S. and $\mathrm{Yu}, \mathrm{H} ., 2011$. Identification of trace organic pollutants in freshwater sources in Eastern China and estimation of their associated human health risks. Ecotoxicology 20: 1099-1106. https:// doi.org/10.1007/s10646-011-0671-8

Statista, 2013. Per capita consumption of fruit juice and nectar worldwide in 2012 and 2013, by country (in liters). Available at: https://www.statista.com/statistics/263205/per-capitaconsumption-of-fruit-juice-worldwide-by-country/

Sudhakaran, M., Ramamoorthy, D., Savitha, V. and Balamurugan, S., 2018. Assessment of trace elements and its influence on physicochemical and biological properties in coastal agroecosystem soil, Puducherry region. Geology, Ecology, and Landscapes 2: 169176. https://doi.org/10.1080/24749508.2018.1452475

Sun, H., Brocato, J. and Costa, M., 2015. Oral chromium exposure and toxicity. Current Environmental Health Reports 2: 295-303. https://doi.org/10.1007/s40572-015-0054-z

Trumbo, P., Yates, A.A., Schlicker, S. and Poos, M., 2001. Dietary reference intakes: vitamin $\mathrm{A}$, vitamin $\mathrm{K}$, arsenic, boron, chromium, copper, iodine, iron, manganese, molybdenum, nickel, silicon, vanadium, and zinc. Journal of the Academy of Nutrition and Dietetics 101: 294.

USEPA, 2015. United state environmental protection agency. Quantitative Risk Assessment Calculations. Available at: https:// www.epa.gov/sites/production/files/2015-05/documents/13.pdf

Varol, M., Sünbül, M.R., Aytop, H. and Yllmaz, C.H., 2020. Environmental, ecological and health risks of trace elements, and their sources in soils of Harran Plain, Turkey. Chemosphere 245: 125592. https://doi.org/10.1016/j.chemosphere.2019.125592

Wang, Q., Liu, J. and Cheng, S., 2015. Heavy metals in apple orchard soils and fruits and their health risks in Liaodong Peninsula, Northeast China. Environmental Monitoring and Assessment 187: 4178. https://doi.org/10.1007/s10661-014-4178-7

Wei, B. and Yang, L.J.M.J., 2010. A review of heavy metal contaminations in urban soils, urban road dusts and agricultural soils from China. Microchemical Journal 94: 99-107. https://doi. org/10.1016/j.microc.2009.09.014

WHO, 2001. World Health Organization. Iron deficiency anemia. assessment, prevention, and control. A guide for programme managers: pp. 47-62.

WHO, 2018. Word Health Organization (WHO). Healthy diet (2018). Available at: http://www.who.int/news-room/ fact-sheets/detail/healthy-diet

Wilberforce, J.O., 2016. Review of metal uptake, plant-metal interaction and transport in plants in view of phytoremediation. IOSR Journals 9: 18-19. 
Xu, L., Wang, T., Luo, W., Ni, K., Liu, S., Wang, L., Li, Q. and Lu, Y., 2013. Factors influencing the contents of metals and as in soils around the watershed of Guanting Reservoir, China. Journal of Environmental Sciences 25: 561-568. https://doi.org/10.1016/ S1001-0742(12)60095-3

Zafarzadeh, A., Bay, A., Fakhri, Y., Keramati, H. and Hosseini Pouya, R., 2018. Heavy metal (Pb, Cu, Zn, and $\mathrm{Cd}$ ) concentrations in the water and muscle of common carp (Cyprinus carpio) fish and associated non-carcinogenic risk assessment: Alagol wetland in the Golestan, Iran. Toxin Reviews 37: 154-160. https://doi.org/10.1080/15569543.2017.1386684

Zahoor, A., Jaffar, M., Saqib, M.J.N. and Science, F., 2003. Elemental distribution in summer fruits of Pakistan. Nutrition \& Food Science 33: 203-207. https://doi. org/10.1108/00346650310499712 